\title{
Editor's Introduction / Présentation du numéro
}

\author{
Jennifer McWeeny \\ Worcester Polytechnic Institute, Worcester, MA, USA \\ jmcweeny@wpi.edu
}

The year 2020 is carving out a singular place in history, like 1939 or 1968 . This is a time when current events weigh so heavily on existing structures that their supports have buckled, laying bare inefficacy and injustice just beneath the surface. In the midst of a global pandemic and the rise of diverse social movements protesting the unequal distribution of bodily vulnerability according to race, gender, class, and other social locations, the weaknesses inherent in our governments, healthcare systems, economies, and societies stamp our lived experience with in-sight - a seeing from within the historical moment as it unfolds.

That the number 2020 evokes the name for optic clarity relative to a certain distance is thus fitting. With this new year, we encounter the urgency of our existential condition with $20 / 20$ vision. The number is also a doubled one ("twenty-twenty"), an appropriate sign of the duplicitous perception common to the social media of our extended, electronic minds, where power struggles between competing political camps surround us with rhetoric, propaganda, and lies that look a lot like truth. ${ }^{1}$ Such features of our era implicate a moment of repetition -20 followed by $20-$ a reprise of prior histories, a twinning of spaces and times. The 2020s, like the 1920s, have come with a roar and have so far lived up to the label "les années folles" (the crazy years), albeit in a manner different from that of its namesake a century ago. This is Deleuzian "repetition with a difference," the concept at the center of his book published in 1968, when protests against capitalism, colonialism, and imperialism erupted across France, the United States, and other countries. ${ }^{2}$

1 The phenomenon of "double vision" or "duplicitous perception" is double-edged in that it is a strategy that can be employed both in the service of oppression and resistance. See María Lugones, "Boomerang Perception and the Colonizing Gaze: Ginger Reflections on Horizontal Hostility," in Pilgrimages/Peregrinajes: Theorizing Coalition against Multiple Oppressions, Lanham, MD, Rowman \& Littlefield, 2003, 151-164, pp. 156, 159, 162-163. María's presence is one of the many great losses of 2020.

2 Gilles Deleuze, Difference \& Repetition, trans. Paul Patton, New York, Columbia University Press, 1994 [1968]. 
Like our lived experiences, this second volume of the relaunched Simone de Beauvoir Studies, volume 31, is imprinted with the date 2020. The current issue is distinctive because it is the first "standard issue" of the new instantiation of the journal. The inaugural volume, volume 30, published in 2019, consists of two special issues: "The New Face of Simone de Beauvoir Studies / Études sur Beauvoir: un nouveau regard" ( $S d B S$ 30.1) and "Beauvoir in Conversation / Dialogues avec Beauvoir" ( $S d B S$ 30.2). Whereas texts included in special issues are selected in virtue of their capacity to speak to a predetermined theme, those that comprise standard issues are considered on an individual basis, so their themes emerge retrospectively, after the texts have been grouped together. A standard issue shows us which questions are foremost in the minds of individual scholars of our era and which patterns repeat across discrete writings from different disciplines and cultural landscapes. In this way, the collection of texts that comprise this issue "reflect an epoch which [seeks] to know itself." 3

Two thematic threads are especially prominent among the introductory matter, articles, book reviews, and interview featured in this issue. First, whether literary, historical, political, or philosophical, each text prioritizes first-person experience and situates that experience in relation to particular social and historical locations occupied by both authors and readers, such as White, Black, French, American, Muslim, Western, non-Western, neocolonial, and trans identities. Second, these texts highlight parts of Beauvoir's oeuvre that have been historically underexplored or misrepresented in the scholarly literature, such as her relationships with Richard Wright and Djamila Boupacha, her relevance to the fields of transgender studies and posthuman studies, her analysis of biology in The Second Sex, her conceptions of literary genres, and her student and travel diaries, memoirs, and unpublished manuscripts.

Following a tradition begun with volume 30, the Simone de Beauvoir Studies Featured Translation / Traduction annuelle is placed as the lead article of the volume. This year's honoree is Margaret A. Simons, whose groundbreaking 1998/1999 essay titled "Richard Wright and Simone de Beauvoir" was translated into French by Marine Rouch. ${ }^{4}$ That Simons has written a text capable of

3 Simone de Beauvoir, Force of Circumstance, trans. Richard Howard, New York, Penguin Books, 1987 [1963], p. 55. Subsequent references to this work are indicated by the abbreviation FCE.

4 Margaret A. Simons, "Richard Wright and Simone de Beauvoir: From the Black Metropolis to 
shifting the entire field of Beauvoir scholarship while also speaking to wider issues of equity and inclusion in the academy will likely come as no surprise to $S d B S$ readers. In 1983, Simons published the landmark article "The Silencing of Simone de Beauvoir: Guess What's Missing from The Second Sex," a study that both exposed sexist reading strategies prominent in the academy and ignited the drive to reclaim Beauvoir's rightful place as a philosopher that has been a primary focus of American and Anglophone academic writing for the past three decades. ${ }^{5}$

Though it is no less groundbreaking than "The Silencing of Simone de Beauvoir," Simons's essay about the erasure of Richard Wright's influence on European thought has yet to receive the same attention in our field. In both cases, Simons shows how the sex and race of each thinker-that Beauvoir is a White woman and Wright is a Black man — comes to bear on their places in national imaginaries and disciplinary canons. As Simons explains, "Ces éléments remettent en question la vision d'une philosophie seulement créée par les hommes blancs européens mais aussi celle qui postule que Richard Wright, écrivain émigré, fut passivement influencé par la philosophie française et n' exerça aucune influence sur les intellectuel.le.s française.e.s." (This evidence challenges the view that philosophy is only the creation of white European men and that Richard Wright, an émigré writer, was a passive recipient of French philosophical influence, exerting no influence himself on French intellectuals. $)^{6}$

In "Simone de Beauvoir, Richard Wright et Le Deuxième Sexe," Simons situates concepts of race and sex in relation to particular, first-person accounts of these locations and argues that Beauvoir's theory of women's oppression in The Second Sex is indebted to Wright's theory of racial oppression. The two authors first met in person in 1947 while Beauvoir was visiting the United States, although she had read Wright's work as early as 1940 and published a number of his stories in the first issues of Les Temps Modernes from 1945 to $1947 .{ }^{7}$ This 1947

the City of Lights," Drum Voices Review, vol. 8, no. 1-2, 1998/1999, pp. 122-135. The essay was revised and reprinted under the title "Richard Wright, Simone de Beauvoir, and The Second Sex," in Simons's book, Beauvoir and "The Second Sex": Feminism, Race, and the Origins of Existentialism, Lanham, MD, Rowman \& Littlefield, 2000, pp. 167-184.

5 Margaret A. Simons, "The Silencing of Simone de Beauvoir: Guess What's Missing from The Second Sex," Women's Studies International Forum, vol. 6, no. 5, 1983, pp. 559-564.

6 The English translation of this passage can be found in Simons, Beauvoir and "The Second Sex," p. 183 .

7 Richard Wright, "Le feu dans la nuée, I-II" ("Fire and Cloud"), trans. Marcel Duhamel, Les Temps Modernes, no. 1, October 1945, pp. 22-47; no. 2, November 1945, pp. 291-319; "Débuts à Chicago" ("The Man Who Went to Chicago"), trans. Marcel Duhamel, Les Temps Modernes, no. 11-12, August-September 1946, pp. 464-497; Black Boy, I-VI (Black Boy), trans. Mar- 
meeting in New York, Simons argues, would prove crucial to the development of Beauvoir's mature philosophy. At this time, Beauvoir became especially attentive to the distinction between assuming a third-person objective perspective on the problem of race, exemplified in Gunnar Myrdal's An American Dilemma, and expressing first-person, autobiographical accounts of the lived experience of Blackness in the ways that Wright does in Native Son and Black Boy. ${ }^{8}$ She was inspired by Wright's approach, and would eventually employ a similar method in relation to woman's situation in the second book of The Second Sex.$^{9}$

Returning to Simons's study in 2020, in the wake of the killings of George Floyd, Breonna Taylor, and Ahmaud Arbery, and global protests on behalf of the Black Lives Matter movement, is especially timely in light of its emphasis on the silencing and erasure of Black voices and lineages. ${ }^{10}$ Furthermore, Simons's essay helps us to form coalitions between different social movements across time and space, from antiracist politics to radical feminism, from Black Lives Matter to \#MeToo, and from the Harlem Renaissance of the 1920 s to the globalized, but fragmented political economies of the 2020s. At the same time that Simons traces lines of historical continuity between antiracist and radical feminist movements, she also notes Beauvoir's awareness of differences between her own experience and those of Black women. Referring to Beauvoir's descriptions in America Day by Day, Simons writes, "Beauvoir quitte le sud des États-Unis sans se faire trop d'illusions sur les possibilités d' une solidarité fém-

cel Duhamel, Les Temps Modernes, no. 16, January 1947, pp. 577-6o9; no. 17, February 1947, pp. 8o6-845; no. 18, March 1947, pp. 989-1031; no. 19, April 1947, pp. 1219-1275; no. 20, May 1947, pp. 1430-1472; no. 21, June 1947, pp. 1642-1678.

8 Gunnar Myrdal, An American Dilemma, 2 vols., New York, Routledge, 1995-1996 [1944]; Richard Wright, Native Son, New York, HarperPerennial, 2005 [1940]; Black Boy, New York, HarperPerennial, 2020 [1945].

9 Simone de Beauvoir, The Second Sex, trans. Constance Borde and Sheila MalovanyChevallier, New York, Knopf, 2010 [1949], p. 41. Subsequent references to this work are indicated by the abbreviation $s$.

10 In recent months, the Presidents of France and the United States have denounced current academic discourses on race. Jeffrey Martin, "Donald Trump Says Critical Race Theory Is 'Like a Cancer,' "Newsweek, September 24, 2020; Françoise Fressoz and Cédric Pietralunga, "Après le déconfinement, l'Elysée craint un vent de révolte: 'Il ne faut pas perdre la jeunesse," Le Monde, June 11, 2020; “Etienne Balibar, Sandra Lougier, Achille Mbembe ...: 'Emmanuel Macron engage le combat non pas contre le racisme, mais contre l'antiracisme,'" Le Monde, June 22, 2020. Notably, speech and discourse about first-person experiences of systemic racism from Black perspectives is seen as especially divisive in these contexts. 
iniste qui dépasserait les divisions raciales" (Beauvoir leaves the South with few illusions of feminist sisterhood cutting across the racist divide). ${ }^{11}$

This question of feminist coalition across racial, economic, and colonial difference is precisely the subject of the second article in the issue, by Deniz Durmuş. ${ }^{12}$ In "Lessons from Beauvoir for a Transnational Feminist Ethics," Durmuş argues that feminist ethics must begin with the recognition that "Western feminists contribute to the oppression of non-Western women." Beauvoir models this capacity for critical self-reflection in many of her writings. For example, in Force of Circumstance, Beauvoir recounts her self-experience during the Algerian war in the following terms: "I was seeing myself through the eyes of women who had been raped twenty times, of men with broken bones, of crazed children: a Frenchwoman." ${ }^{13}$ Further she intimates, "I'm French.' The words scalded my throat." ${ }^{14}$ This passage recalls another from America Day by Day when Beauvoir and her traveling companion see racially segregated restaurants and restrooms in Texas: "[I]t was our own skin that became heavy and stifling, its color making us burn."15 At the level of lived experience, Beauvoir describes benefiting from the oppression of others as dizzying and uncomfortable like a sweltering heat; it "scalds" and "burns" the sense of self that is usually shielded by systemic racism, colonial legacies, and the rise of neocolonialism.

Durmuş's article offers timely advice for feminists who, like Beauvoir, are caught in the heat of existential tensions, such as those of being both French and anti-French, American and anti-American, White and antiracist, imperialist and anticolonialist, oppressor and oppressed. Durmuş begins with a practical question: "Is it ever possible for feminists from privileged and/or dominant geographies to comment/interfere ethically on local women's issues?" In her response, Durmuş draws our attention to Beauvoir's political writings and

11 See also Janine Jones, "When Black Female Presence in Beauvoir's L'Invitée Is (Seemingly) Not Invited to The Second Sex," Simone de Beauvoir Studies, vol. 30, no 1, 2019, pp. 87109 .

12 See also Chala Chafiq, Rendez-vous iranien de Simone de Beauvoir, Donnemarie-Dontilly, Éditions iXe, 2019, and Nathalie Nya, Simone de Beauvoir and the Colonial Experience: Freedom, Violence, and Identity, Lanham, MD, Lexington Books, 2019.

$13 \quad F C E$, pp. 381-382.

14 FCE, p. 397.

15 Simone de Beauvoir, America Day by Day, trans. Carol Cosman, Berkeley, University of California Press, 1999 [1948], p. 204. See also Joy D. Simmons, "Simone de Beauvoir's Racial 'Others': An Exploration of Whiteness in America Day by Day," Simone de Beauvoir Studies, vol. 24, 2007-2008, pp. 66-75. 
activism, and especially to those essays that discuss the French colonization of Algeria and the Djamila Boupacha case. Durmuş first outlines four problems that often characterize Western women's engagements with non-Western feminisms: ignorance about local experience, the assumption of superiority, paternalism, and lack of self-critique. She then suggests that the anticolonial activist strategies that Beauvoir employed in support of Djamila Boupacha lay the groundwork for a transnational feminist ethics - an ethics where White, Western feminists can support, rather than undermine, the diverse modes of resistance of non-Western women and people of color.

Although Beauvoir acknowledges and reflects upon her own complicity in the oppression of others, she also shows us that guilt need not lead to political paralysis. For example, in her anticolonial activism, Beauvoir gave voice to Boupacha's experience of torture by restricting herself to Boupacha's own description of the events and respecting Boupacha's Muslim values, even though Beauvoir did not share these values herself. ${ }^{16}$ By enacting such strategies, Western women can minimize the problematic tendencies that Durmuş identifies. Contemporary feminists would therefore do well to look to Beauvoir's activism as a model when forging feminist coalitions across the global North and the global South, and between White women and Women of Color, women of the bourgeoisie and working-class women, and women of different faiths, including Islam, Christianity, Judaism, Hinduism, Buddhism, and atheism.

Whereas Simons and Durmuş focus on underexplored aspects of Beauvoir's published works, Eric Levéel's article, "Simone de Beauvoir: s'écrire, se dire, se promener. Le triptyque de 1946," further expands the reader's purview through an interpretation of one of Beauvoir's unpublished and intimate manuscripts. Beauvoir's 1946 diary covers the period from April 30, 1946 to August 31, 1946, and gives readers a peek into what Beauvoir was thinking about at this pivotal time in her life, which took place after the war but before her first journey to the United States, where she met Wright in 1947. Beauvoir saw her friend, Alberto

16 Simone de Beauvoir, "Pour Djamila Boupacha," Le Monde, June 2, 1960. The Prix Simone de Beauvoir pour la liberté des femmes is an annual award that continues Beauvoir's activist commitments by recognizing and supporting contemporary, local movements on their own terms. For example, the Prix Simone de Beauvoir 2020 was presented to representatives of the "Collectif 49o," Leila Silmani, Sonia Terrab, and Karima Nadir, in Paris on Beauvoir's birthday. The Collectif 490 was organized to eliminate the Moroccan penal code 490 that prohibits sex outside of marriage, and to advocate for sexual freedom for women and others generally. Collectif 49o, website, https://www.collectif 490.com/. 
Giacometti, frequently during the spring of 1946, and it was he who encouraged her to keep a diary while they were having dinner one night. Beauvoir likewise inspired Giacometti's artistic creativity. According to the Giacometti Foundation, he made eight sculptures of her face that year and four sketches as he worked on the sculptures, including the sketch featured in the signature cover design of the relaunched Simone de Beauvoir Studies. ${ }^{17}$ Levéel underlines the importance of this transitional period in Beauvoir's life when the young woman reached the end of her thirties and began her mature years as a writer. Similarly, Simons deems this time a "turning point" for Beauvoir because it immediately preceded her decision to write The Second Sex. ${ }^{18}$

Levéel refers to the unpublished diary as "the triptych of 1946 " because it can be divided into three parts that approximately correspond to three countries that she visited during this period: Switzerland, Italy, and France. This rough organization is characteristic of the 1946 diary, which is relatively short, punctuated by gaps in entries, and inclusive of hurried or incomplete passages. It has the feel of fresh, spontaneous writing that has not yet been edited. Levéel argues that rather than detract from our understanding of Beauvoir and her ideas, the short and unfinished nature of the diary points us to her theory of literary genres in general and her theory of the diary in particular. A diary is written in the first person for the purpose of documenting experiences as they unfold. As Beauvoir writes in the final entry on August 31, 1946, "Il faudrait le faire [écrire dans ce journal] vraiment un petit moment chaque jour et noter les choses dans leur jaillissement" (It is important to do it [write in this journal] for a moment each day and record the outpouring of things in the original stream of experience) $\cdot{ }^{19}$ Memoirs recall experiences at a temporal remove from when they happened, but diary entries often engage life in real time. This tendency to write the present is especially common in a "travel diary," whose goal is often

17 Alberto Giacometti Database, webpage, Giacometti Foundation, https://www.fondation -giacometti.fr/en/database.

18 Margaret A. Simons, "Beauvoir and The Second Sex: The Turning Point," Simone de Beauvoir Studies, vol. 3o, no. 1, 2019, pp. 127-147.

19 Unpublished manuscript quoted in Levéel's article, p. 81, my translation. See Levéel, p. 69, note 1 for bibliographical information. Likely overlooked due to inconsistent English translations of the terms across Beauvoir's oeuvre, the concepts of "jaillissement" (outpouring) and "débordement" (overflow) are consistently used as phenomenological figures in Beauvoir's philosophy to signal the original flow of prereflective consciousness that exists before and beyond language. They are also associated with the leaky and fluid character of women's bodies. See Jennifer McWeeny, "The Feminist Phenomenology of Excess: Ontological Multiplicity, Auto-Jealousy, and Suicide in Beauvoir's L'Invitée," Continental Philosophy Review, vol. 45, no. 1, 2012, 41-75, pp. 63-64. 
to take snapshot impressions of events during the journey, serving as a kind of photo album, but with words instead of images.

Perhaps the most distinctive aspect of the diary genre is that its intended audience is also its author in most cases. A diary therefore fosters the writer's self-relationship rather than the relationship between writer and reader, or between an author and her public. ${ }^{20}$ Levéel goes so far as to suggest that the genre is marked by "auto-épistolarité" (auto-epistolarity); a diary is a collection of letters to oneself. Because the diary's audience is the self, diary-writing foregrounds the pleasure of the act of writing, including "le plaisir tactile de tracer des mots sur le papier" (the tactile pleasure of tracing words on paper). Levéel's study thus sparks a number of questions about the sensual and practical differences between the mediums (genres) in which Beauvoir worked, and especially in regard to those mediums that are pursued in the first person and mostly left unpublished: the diary (le journal), the notebook (le carnet), letters and correspondence (les lettres et la correspondence), travel-writing (l'écriture de voyage), autobiography (l'autobiographie), self-portrait (l'autoportrait), and eyewitness accounts (les témoinages).

The question of genre is also foregrounded in "Au-delà de 'l' entrée de Simone de Beauvoir dans la Pléiade," a special interview conducted by the Assistant Editor of Simone de Beauvoir Studies, Claudia Bouliane. Bouliane conceived of and arranged the interview to give $S d B S$ readers a glimpse into the editorial motivations and technical decisions that project directors Sylvie Le Bon de Beauvoir, Jean-Louis Jeannelle, Éliane Lecarme-Tabone, and their team of specialist editors enacted in the compilation and presentation of Beauvoir's Mémoires..$^{21}$ Moving beyond (au-delà) the frame of media attention and popular queries about the symbolic meaning of the publication of Beauvoir's work in the prestigious and canonizing Pléiade series by Gallimard, Bouliane's carefully crafted questions invite responses that bring readers into the thickness of the text itself, thus revealing the significant scholarly apparatus and editorial expertise that lie at the heart of this project. ${ }^{22}$

20 For recent scholarship on Beauvoir's relationship with her readers, see Anne Strasser, "Simone de Beauvoir et ses lecteurs: de personne à personne," Simone de Beauvoir Studies, vol. 30, no. 1, 2019, pp. 110-126, and Marine Rouch, "Simone de Beauvoir et ses lectrices: hypothèse d'une influence réciproque (1949-1971)," Simone de Beauvoir Studies, vol. 3o, no. 2, 2020, pp. 225-251.

21 Simone de Beauvoir, Mémoires, 2 vols., ed. Jean-Louis Jeannelle and Éliane LecarmeTabone, Paris, Gallimard, collection Bibliothèque de la Pléiade, 2018.

22 See also Michel Kail's review of Mémoires in Simone de Beauvoir Studies, vol. 30, no. 1, 2019, pp. $181-192$. 
In the beginning of the interview, Jeannelle explains the choice to make the first Pléiade edition of Beauvoir's works a collection of her memoirs rather than a collection of her novels or philosophical essays. More so than these other genres, Beauvoir's memoirs have consistently captured the attention of readers over time, and this interest has only increased due to the proliferation of lifewriting and "l'écriture de soi" (writing on the self) taking place in the twentyfirst century. ${ }^{23}$ In Jeannelle's words, "Beauvoir suscite, en France du moins, une véritable fascination en raison de ses écrits à la première personne" (In France at least, Beauvoir elicits an absolute fascination due to her writings in the first person). Beauvoir's life is also an object of fascination because it is not hers alone: in her memoirs, she writes herself from within her situation and the movement of history. According to Jeannelle, the genre of memoir enables the author to enact an expert balance between the personal and the historical that brings the reader to experience this history and situate herself/himself/theirself in relation to it.

Mémoires includes six texts: Memoirs of a Dutiful Daughter (1958), The Prime of Life (1960), Force of Circumstance (1963), A Very Easy Death (1964), All Said and Done (1972), and Adieux: Farewell to Sartre (1981). This editorial arrangement calls for us to adopt a new reading strategy in regard to Beauvoir's works: reading these texts together rather than separately, we witness a distinctive continuity that marks Beauvoir's narrative, which moves from her childhood before the First World War, through her educational formation and experience of the Second World War, to her participation in feminist and anticolonial activism in the 196os and 1970s, and ultimately to her old age. We also notice that Beauvoir's embodiment of the genre of memoir is syncretic rather than purist: her memoirs are themselves comprised of several genres, including extracts from her diaries and correspondence, as well as portions devoted to autobiography, autoportrait, and eyewitness accounts. ${ }^{24}$ Finally, the presence of a self-conscious intention to write a memoir seems a defining aspect of the genre as the editors of the Pléiade series understand it. They therefore selected the six texts that Beauvoir located within her memoir project after she formed the intention in 1958 , and excluded earlier writings such as

23 I identify the "twenty-first-century self" and its modes of expression as one of four themes characterizing the present state of Beauvoir studies in "Introduction / Présentation," Simone de Beauvoir Studies, vol. 30, no. 1, 2019, 1-27, pp. 12-16.

24 As Levéel points out, a portion of Beauvoir's 1946 diary is reproduced in Force of Circumstance, and her diaries and letters often served as preparation for her memoirs. FCE, pp. 78-101. $^{-10}$ 
America Day by Day (1948), a work that could potentially be classified as a "memoir" according to alternative criteria.

The core texts included in Mémoires are surrounded by a rich scholarly apparatus, which includes an editor's introduction, a chronology by Sylvie Le Bon de Beauvoir, relevant excerpts from Beauvoir's published and unpublished manuscripts, extensive notes and analysis on each text, appendices that feature three interviews with Beauvoir from the 196os, a bibliography, and an index. Bouliane observes that this apparatus makes frequent reference to American and Anglophone analyses, a feature that may be unusual for works of French literature in the Pléiade series. Éliane Lecarme-Tabone explains that the international scope of supporting scholarship is justified due to the differential historical reception of Beauvoir's oeuvre by Francophone and Anglophone readers. She notes, "[À] partir des années 1980, la recherche française a manifesté une certaine désaffection à l'égard de l'œuvre de Beauvoir, tandis que les chercheuses britanniques et américaines lui vouaient un intérêt vif et soutenu" (Since the 1980s, French scholarship has displayed a certain disaffection in regard to Beauvoir's oeuvre while British and American researchers have demonstrated a lively and unflagging interest in it). ${ }^{25}$ French academics have recently devoted renewed attention to Beauvoir, as is evidenced by the inclusion of Mémoires d'une jeune fille rangée (Memoirs of a Dutiful Daughter) on the 2019 agrégation examination in modern literature. Nonetheless, important differences exist in the ways that Francophone and Anglophone scholars approach her work. In broad terms that admit of notable exceptions, we could say that contemporary Anglophone scholarship has historically centered the question of gender in Beauvoir studies, whereas Francophone scholarship has been more attentive to the question of genre. Moreover, American scholars tend to read Beauvoir as a philosopher and thus they prioritize The Second Sex. French scholars, however, are more likely to emphasize Beauvoir's literary contributions. ${ }^{26}$ That the first French edition of Beauvoir's collected works begins

25 See also Michèle Le Dœuff, "Towards a Friendly, Transatlantic Critique of The Second Sex," trans. Emily Grosholz, in The Legacy of Simone de Beauvoir, ed. Emily Grosholz, New York, Oxford University Press, 2004, pp. 22-36, and Toril Moi, Simone de Beauvoir: The Making of an Intellectual Woman, 2nd ed., New York, Oxford University Press, 2009 [1994], pp. 93-114.

26 The recent publication of a special issue of Philosophie devoted to Beauvoir's The Second Sex indicates that Beauvoir's place in the French university is shifting. Manon Garcia and Raphaël Ehrsam, eds., "Perspectives philosophiques sur 'Le Deuxième Sexe' de Simone de Beauvoir paru il y a 70 ans," special issue, Philosophie, vol. 144, January 2020. See also Michèle Le Dœuff, Hipparchia's Choice:An Essay concerning Women, Philosophy, etc., trans. Trista Selous, New York, Columbia University Press, 2007 [1989]. 
with her memoirs, and the first English edition begins with Philosophical Writings is evidence of these cultural patterns. ${ }^{27}$

As a central part of its Pléiade collection since 196o, Gallimard publishes one illustrated biographical compendium per year about an author in the series. Beauvoir is the subject of the 2019 "Album," which serves as an intimate companion to the two-volume Mémoires. ${ }^{28}$ Due to her lifelong friendship with Beauvoir, Sylvie Le Bon de Beauvoir's authorship of the Album Simone de Beauvoir challenges the traditional methodological expectation that biographical material would be approached in the third person, thus rendering this Album a distinctive and nuanced contribution to the Pléiade collection. With words that signal the personal impact Beauvoir had off the page at the level of experience, Le Bon de Beauvoir tells Bouliane, "Parler d' elle c'est parler de moi, et il me semble fausser notre vérité en l'objectivant" (To speak of her is to speak of myself, and it seems to me false to our truth to speak of it objectively).

Megan Burke's article, "On Bad Faith and Authenticity: Rethinking Genderless Subjectivity," shares with the editors of Mémoires an emphasis on firstperson experience. Evoking the first-person perspective from a phenomenological rather than literary angle though, Burke also reflects the primacy of both philosophy and the topic of gender in American and Anglophone scholarship. Specifically, she considers the lived experience of "genderless," "genderneutral," and "agender" subjectivities in relation to Beauvoir's concept of "bad faith" (mauvaise foi). These subjectivities do not entail identification with any gender, and, as such, they could be said to fall under the umbrella of "trans subjectivities" insofar as they traverse the conventional social categories of sex and gender and confound their limits.

Even though Beauvoir is critical of biological essentialism in regard to sex, her insistence on the persistence of social meanings at the level of individual experience opens the question of whether her theory of women's oppression is hostile toward transgender and genderless identities. For example, Beauvoir writes that "the individual is not free to shape [the idea of femininity] as she

27 Simone de Beauvoir, Philosophical Writings, ed. Margaret A. Simons with Marybeth Timmerman and Mary Beth Mader, Urbana, University of Illinois Press, 2004. This is the first volume of the seven-volume Beauvoir Series published by University of Illinois Press. Collections of Beauvoir's essays and writings have appeared in France over the years, but Mémoires is the first to group multiple book-length works together in one edition.

28 Sylvie Le Bon de Beauvoir, Album Simone de Beauvoir, Paris, Gallimard, collection Bibliothèque de la Pléiade, 2018. 
pleases" and that even a rejection of femininity or heterosexuality is so defined by established norms that "neutrality is impossible."29 She continues, "In refusing feminine attributes, [the woman] does not acquire virile ones; even the transvestite does not succeed in making a man of herself [ faire d'elle-même un homme]: she is a transvestite." 30 The idea that third-person perceptions imprint the very structure of first-person experience in oppressive contexts-an idea that finds support in the writings of Beauvoir, Frantz Fanon, and others-has led many contemporary feminists to reject the ontological possibilities that a person who was not born and raised a girl could ever become a woman, and that a person who was born and raised as a girl could reverse the process and "unbecome" a woman. ${ }^{31}$ According to this interpretation, those individuals who believe that their genders can be changed at will are denying the ways that power relations structure their experience and, inasmuch as this is the case, are likely assuming an attitude of bad faith toward their gender.

Burke claims that it is problematic to equate genderless subjectivities with bad faith in this manner, and observes that undermining a person's first-person ascription of their own gender in favor of social conventions paradoxically upholds many of the power relations that feminists work to dismantle. In order to overcome this dilemma, she insists that we see the question of genderless and trans subjectivities as a matter of ethics rather than of ontology or epistemology. When feminists approach the question of genderless subjectivities from an ontological perspective, they affirm the harmful and sexist norms of, first, believing a person's gender presentation to be indicative of her/his/their genital status and, second, equating a person's gender with this perceived status. Denying someone's avowal of a genderless subjectivity on these grounds therefore amounts to assuming a kind of third-person, epistemic authority in regard to another's self-experience: the observer of the other's gender presentation knows her/his/their gender best and is therefore in a position to legitimate that gender to others. Under these conditions, expressing one's own gender identity to another could never be done with authenticity; if gender is in the

$29 S s$, p. 724, translation modified, emphasis added.

30 ss, p. 724, translation modified; Simone de Beauvoir, Le Deuxième Sexe, vol. 2, Paris, Gallimard, 1976 [1949], p. 601.

31 See, for example, Frantz Fanon, Black Skin, White Masks, trans. Charles Lam Markmann, New York, Grove Press, 1967 [1952], p. 110. On the relationship between oppression and the perspectival structure of consciousness, see Jennifer McWeeny, "The Second Sex of Consciousness: A New Temporality and Ontology for Beauvoir's 'Becoming a Woman," in "On ne naît pas femme: on le devient...": The Life of a Sentence, ed. Bonnie Mann and Martina Ferrari, New York, Oxford University Press, 2017, pp. 231-273. 
eye of the beholder, then those who avow genderless subjectivities are prohibited from being ethical agents.

Alternatively, Burke suggests that the person who avows a genderless subjectivity is "desiring to disclose being" rather than "desiring being" tout court. ${ }^{32}$ Not only is the genderless person assuming their freedom by working to destabilize harmful social meanings and project themselves into a different future, but they are also presenting their authentic self to the other and entering into the risk and responsibility of forging an ethical society. Like Beauvoir's description of the girl who "makes herself a lesbian" (se faire lesbienne), the person who avows a genderless subjectivity is assuming an attitude that is chosen in situation and that can be an expression of bad faith or authenticity depending on the "mood and desire of the avowal."33 Affirming rather than denying our existential condition, which consists both in the temptation toward bad faith and the means to assume our freedom, is not only the ground of an ethics, but also of a "trans-inclusive feminism."

The author of the final article in the issue, Erika Ruonakoski, shares two motivations with Burke: the desire to construct a more nuanced interpretation of Beauvoir's philosophical concepts than presently exists, and the desire to reconsider the scope and applicability of Beauvoir's theory of oppression. Where Burke's focus is the relationship between genderless subjectivities and bad faith, Ruonakoski provides a critical analysis of Beauvoir's notion of immanence to illuminate a theory of oppression that can bridge the humannonhuman divide. In "When Living Is Only Not Dying: Immanence and Animals in Beauvoir's Discussion of Oppression," Ruonakoski employs two notable strategies that yield a fine-grained account of immanence. First, Ruonakoski does not simply look to one of Beauvoir's texts to discern the meaning of immanence, but instead follows the development of Beauvoir's thinking across several of her essays, from Pyrrhus and Cineas and The Ethics of Ambiguity to The Second Sex. ${ }^{34}$ Second, Ruonakoski situates Beauvoir's understanding of immanence in relation to those of other philosophers whom she references in these works, including G.W.F. Hegel, Alexandre Kojève, Jean-Paul Sartre, and Maurice Merleau-Ponty.

32 Simone de Beauvoir, The Ethics of Ambiguity, trans. Bernard Frechtman, New York, Citadel Press, 1976 [1947], p. 24. Subsequent references to this work are indicated by the abbreviation $E A$.

$s s$, p. 431, translation modified. See also $s s$, p. 436. On the mistranslation of the reflexive verb "se faire" in English editions of The Second Sex, see McWeeny, "The Second Sex of Consciousness," pp. 243, 269, note 35 .

34 Simone de Beauvoir, Pyrrhus and Cineas, trans. Marybeth Timmerman, in Philosophical Writings, ed. Simons with Timmermann and Mader, pp. 89-149; EA; $s$. 
Ruonakoski maintains that there are at least two conceptions of immanence at play in Beauvoir's writings. In Pyrrhus and Cineas and The Ethics of Ambiguity, Beauvoir posits a sharp distinction between human and nonhuman life, and, following Kojève, associates immanence with the latter. ${ }^{35}$ According to this view, nonhuman animals such as cows or ants "never say 'I'" and are thus unable to differentiate themselves from the herd or hive through selfconsciousness and intersubjective recognition. Lacking the capacity for individuation, nonhuman animals are likewise incapable of the self-surpassing that constitutes transcendence. However, in the "Biology" chapter of The Second Sex, Beauvoir's understanding of immanence transforms and displays a Hegelian gradualism whereby the capacity for individuation, and therefore transcendence, is a matter of degree rather than kind. This second meaning of immanence is compatible with claims expressed elsewhere in The Second Sex that "every living thing indicates transcendence, and that a project is in the making in every function," thus implying that plants and nonhuman animals can assume a kind of freedom. ${ }^{36}$

Ruonakoski concludes that Beauvoir's conception of immanence is "outdated" insofar as she associates immanence with species life, necessity work, and female functions. Because all beings exhibit both immanence and transcendence to some degree and because the immanent aspects of existence manifest differently in different species, we should resist the urge to define oppression as a return to immanence. Instead, oppression is best construed as a "deprivation of transcendence." In a move not unlike Burke's, Ruonakoski rejects the tendency to graft the distinction between immanence and transcendence onto ontological categories, equating the lives of nonhuman animals, plants, and women with immanence and those of humans and men with transcendence. Beyond ontology, we must recognize the political imperative to eradicate limits to "the movement of transcendence in all its different forms," whether the existential project in question is undertaken by a human, an animal, a vegetable, or a mineral. We must strive to foster the conditions under which living can be more than "only not dying." In 2020, from places of quarantine, protest, confinement, and screen-only sensuality, this distinction between mere survival and thriving is rendered especially concrete for us, albeit more so for those who have rarely worried about survival until now than for others.

35 For a different interpretation of Beauvoir's view on the distinction between humans and nonhumans, see Sonia Kruks, "For a Modest Human Exceptionalism: Simone de Beauvoir and the 'New Materialisms,' Simone de Beauvoir Studies, vol. 30, no. 2, 2020, pp. 252-274. 
The relaunched Simone de Beauvoir Studies was explicitly conceived as a medium for inspiring future phases of Beauvoir scholarship through the crosscultural and bilingual exchange of ideas. Just as we gain a new perspective on the six individual texts that comprise Beauvoir's Mémoires when we read them collectively, we are led to new insight and inspiration when we read Francophone and Anglophone scholarship side-by-side in a single publication, and when we enlarge access to global scholarship with the Featured Translation / Traduction annuelle initiative. The twelve contributors to this issue hail from institutions based in seven countries: Austria, Canada, Finland, France, Ivory Coast, South Africa, and the United States. Additionally, if we consider the authors of the books that are reviewed here, we should extend this list by two more: Iran and the United Kingdom. Moving into the 2020s, at the dawn of a new decade of Beauvoir studies, we have moved beyond "a friendly, transatlantic critique" that centers French and American scholarship to a cutting-edge, global conversation. ${ }^{37}$ This capacity to transcend national and disciplinary networks as well as institutional allegiances that structure our knowing for the sake of engaging in rigorous and relevant dialogue is perhaps the most distinctive feature of this publication.

In this era of in-sight, 20/20 vision, and perspectival multiplicity, the ocular metaphors of the seventeenth and eighteenth centuries that survey from above according to the light of universal, disembodied reason no longer have much purchase. The kinds of vision suggested by "the Sirian point of view," "the eagle's eye," "the God trick," and "the view from nowhere" are in tension with the seeing of the new millennium, when we cannot help but recognize that the viewer's bodily situation and cultural context are integral to what she/he/they sees. ${ }^{38}$ This new way of looking may therefore be more visceral than visual, and, in a circling of time, may be one that Beauvoir and her companions who lived through the years 1939 and 1968 may have already anticipated. Ours is an existential perception that follows not Cartesian lines and high-altitude perspec-

37 Le Dœuff, "Towards a Friendly, Transatlantic Critique."

38 See especially Emmanuel de Saint Aubert's discussion of Beauvoir's reference to the Sirian's point of view in Pyrrhus and Cineas, which inspired Merleau-Ponty's later discussions of the eagle-eye view and high-altitude thinking (la pensée de survol). Emmanuel de Saint Aubert, "The Blood of Others: Maurice Merleau-Ponty and Simone de Beauvoir," trans. Jennifer McWeeny, Simone de Beauvoir Studies, vol. 3o, no. 1, pp. 33-66, pp. 64, note 100, p. 65, note 103. See also Donna J. Haraway, "Situated Knowledges: The Science Question in Feminism and the Privilege of Partial Perspective," Feminist Studies, vol. 14, no. 3, 1988, pp. 575-599; María Lugones, "Tactical Strategies of the Streetwalker / Estrategias Tácticas de la Callejera," in Pilgrimages/Peregrinajes, pp. 207-237; Thomas Nagel, The View from Nowhere, New York, Oxford University Press, 1986. 
tives, but the corporeal coordinates of love and loss, fear and hope, distance and touch, isolation and connection.

The incipit of Beauvoir's first published book, L'Invitée (She Came to Stay), doubles as an incipit to Beauvoir's oeuvre as a whole: "Françoise leva les yeux" (Françoise raised her eyes)..$^{39}$ The contours of Beauvoir's writings look up and out, breaking the private and solipsistic flow of interiority, scanning beyond first- and third-person perspectives to the second person-to you. We are shaken out of shortsightedness and political apathy "when the common fate becomes our own - when we are struck by sickness, a shattered relationship, or bereavement." ${ }^{40}$ We who have lived the impact of 2020 , which hits like a meteor and reveals, as the dust settles, the meaning and meaninglessness of our lives, find in-sight and incitement to act in our lived experience. Now is the time to raise our eyes and envision a future where we all can thrive.

39 Simone de Beauvoir, L'Invitée, Paris, Gallimard, 1972 [1943], p. 1, translated by Yvonne Morse and Roger Senhouse as She Came to Stay, New York, W.W. Norton, 199o, p. 11.

40 Simone de Beauvoir, The Coming of Age, trans. Patrick O'Brian, New York, W.W. Norton, 1996 [1970], p. 283 . 